\title{
Molecular Phylogeny of Arctic Microbes Using Metagenomic Approach
}

\author{
Debraj Ray1, Shylaja Naciyar Mohandass², Pranab Roy ${ }^{*}$ \\ ${ }^{1}$ Department of Biotechnology, Burdwan University, Burdwan, India \\ ${ }^{2}$ National Facility for Marine Cyanobacteria, Bharathidasan University, Tiruchirappalli, India \\ ${ }^{3}$ Department of Biotechnology, Haldia Institute of Technology, Haldia, India \\ Email: debrajrng@gmail.com, shylajanachiyar@gmail.com,
}

Received 20 September 2014; revised 2 November 2014; accepted 24 December 2014

Copyright (C) 2014 by authors and Scientific Research Publishing Inc.

This work is licensed under the Creative Commons Attribution International License (CC BY). http://creativecommons.org/licenses/by/4.0/

(c) (i) Open Access

\begin{abstract}
Metagenomic approach to the characterization of uncultured and mixed bacterial consortium has been used in this study for a few arctic micro-organisms. Arctic soil, collected from one spot at $\mathrm{Ny}$ Alesund in Svalbard was used as the source of such organisms and enriched in culture medium. Only psychrotrophic microbes were chosen which could grow from $5^{\circ} \mathrm{C}$ to $20^{\circ} \mathrm{C}$. Total genomic DNA isolated from the consortium was used as template for amplifying the 16S rRNA genes using the conserved forward and reverse primers. The amplified mixture of $1.4 \mathrm{~kb}$ DNA was cloned in pGEMT Easy vector and individual $16 S$ rDNA sequences were determined by automated sequencing. A phylogenetic tree was constructed using MEGA 5 software which enlists 19 isolates in the consortium. Most of these arctic bacteria were Bacillus species as these were isolated from a single spot.
\end{abstract}

\section{Keywords}

Metagenomics, 16S rRNA, Molecular Phylogeny

\section{Introduction}

Microorganisms constitute the majority of all life forms present in the biosphere [1]. Their total number is estimated to about $10^{30}$ [2], while the microbial diversity is estimated to be about $10^{6}$ to $10^{8}$ [3]. Thus classification of microorganisms, establishing their phylogenetic relationship can enrich our understanding of microbial ecology. Normally, characterizing a microbe involves its isolation in pure state, followed by microbiological and biochemical characterization as per Bergey's manual. However, it is estimated that only $1 \%$ of the total bacterial biodiversity is culturable in the laboratory using different media. Metagenomics is the study of the genomes of

*Corresponding author. 
whole communities of microbes. Instead of isolating individual pure colonies on nutrient medium plates, one can analyze the whole consortium of microbes by metagenomic approach. Craig Venter (2004) published one of the pioneering studies in sequencing the Sargasso Sea micro-organisms [4] Using shotgun sequencing of the mixture of genomic DNAs isolated from Sargasso Sea, it was established that the water contained about 1800 varieties of microbes. The study found 150 new bacterial and Archaea species and more than 1.2 million new genes. Recent approach of metagenomics involving direct isolation of 16S rRNA gene and sequencing has proved to be a powerful technique both for studying diversity as well as to look out for functional aspects [5]-[7]. Pace et al. [8] first reported direct cloning of environmental DNA using this approach.

Here we describe the extraction of DNA from the enrichment culture of Arctic soil samples, the PCR amplification of 16S RNA genes, the cloning of these genes in pGEM-T Easy vector, the sequencing using universal primers of SP6 and T7 promoters present in the vector and their phylognetic analysis using bioinformatic tools like MEGA 5 software.

\section{Materials \& Methods}

Soil Samples: The soil samples were collected from Ny Alesund $\left(79^{\circ} \mathrm{N}, 11^{\circ} \mathrm{E}\right)$, Svalbard, Norway under a project sponsored by NCAOR (National Centre for Antarctic and Ocean Research, Goa, India). 1 gm soil sample was incubated in $100 \mathrm{ml}$ Luria broth at $20^{\circ} \mathrm{C}$ for 48 hours. About $50 \mu \mathrm{l}$ of the culture was transferred to $5 \mathrm{ml} \mathrm{Lu-}$ ria broth for enrichment. Bacterial cells were harvested thereafter.

DNA Extraction: Bacterial cells were suspended in $1 \mathrm{ml}$ glucose Tris EDTA buffer ( $25 \mathrm{mM}$ glucose, $50 \mathrm{mM}$ Tris-HCl, pH 8.0, $10 \mathrm{mM}$ EDTA). $50 \mu \mathrm{l}$ of Lysozyme of concentration $10 \mathrm{mg} / \mathrm{ml}$ was added to it, this mixture was kept at $37^{\circ} \mathrm{C}$ for 30 minutes. SDS was then added to $1 \%$ concentration and kept for $1 \mathrm{hr}$ at $37^{\circ} \mathrm{C}$. PhenolChloroform mixture $(1: 1 \mathrm{v} / \mathrm{v})$ was added in equal volume to the mixture. The mixture was shaken for $5 \mathrm{~min}$, and then centrifuged at 10,000 rpm for 10 minutes. The upper layer was taken and the phenol-chloroform extraction was repeated, again the upper layer was taken. $3 \mathrm{M} \mathrm{Na}$-acetate, $\mathrm{pH} 5.1$ was added at $1 / 10^{\text {th }}$ the volume of the above extract, and double volume cold ethanol was added, the mixture was kept overnight at $-20^{\circ} \mathrm{C}$.

The mixture was centrifuged at 10, $000 \mathrm{rpm}$ for $10 \mathrm{~min}$; the pellet was treated with $70 \%$ ethanol and was vortexed. Centrifugation was done at $10,000 \mathrm{rpm}$ for 5 minutes. The pellet so obtained was dried at $37^{\circ} \mathrm{C}$. It was dissolved in $0.25 \mathrm{ml}$ TE buffer (10 mM Tris-HCl, pH 8.0, $1 \mathrm{mM}$ EDTA). $10 \mu \mathrm{l}$ of the above was tested on $0.8 \%$ agarose gel electrophoresis ( $0.2 \mathrm{gm}$ agarose in $25 \mathrm{ml} 1 \mathrm{X}$ TAE buffer ( $40 \mathrm{mM}$ Tris-Acetate, $\mathrm{pH} 8.3$ and $1 \mathrm{mM}$ EDTA) and $1 \mu \mathrm{g} / \mathrm{ml}$ Ethidium bromide solution).

PCR for Amplification of 16S rDNA: A master mixture for 12 tubes containing $25 \mu \mathrm{l}$ final reaction volume was prepared according to the following composition, $30 \mu \mathrm{l} 10 \mathrm{X}$ buffer with $\mathrm{MgCl}_{2}(1.5 \mathrm{mM}), 6 \mu \mathrm{l}$ of $10 \mathrm{mM}$ dNTP, $24 \mu \mathrm{l}$ universal forward primer (27F: 5'AGA.GTT.TGA.TCC.TGG.CTC.AG3'), $24 \mu \mathrm{l}$ of reverse primer (1492R:5' TAC.GGY.TAC.CTT.GTT.ACG.ACT.T3') of 20 pmoles/ $\mu$ concentration, $6 \mu 1$ Taq Polymerase of 5 units/ $\mu 1$ and $186 \mu l$ water. The mixture was divided in 12 tubes with $23 \mu l$ each, $2 \mu 1$ of genomic DNA of the mixed consortium as template was added to get the final $25 \mu \mathrm{l}$ reaction volume. The thermo-cycler was programmed according to the following, 5 minutes of denaturation at $94^{\circ} \mathrm{C}$ followed by 30 cycles at $94^{\circ} \mathrm{C}$ for 1 minute, 45 seconds at $52^{\circ} \mathrm{C}$ annealing and $72^{\circ} \mathrm{C}$ for 3 minutes of extension time. The product was tested on $1.5 \%$ agarose gel electrophoresis.

\section{1. pGEM-T Vectors}

The pGEM-T Easy vector (Promega Corp) was used for the construction of recombinant plasmids. pGEM-T vectors are linearized vectors with a single 3' thymidine at both the ends. The overhanging $\mathrm{T}$ ends prevents recirculization of vectors and is complementary to the extra A residue at the 3'-ends of the products of PCR [9] [10]. The pGEM-T vectors have T7 and SP6 phage promoters flanking multiple cloning sites within $\alpha$-peptide coding region of the enzyme $\beta$-galactosidase. Insertional inactivation of $\alpha$-peptide region allows selection by blue/white method, using Isopropyl thiogalactoside (IPTG) as the inducer and 5-Bromo, 4-chloro, 3-Indolyl $\beta$-galactoside as the chromogenic substrate.

Ligation of PCR Amplicons of 16S rDNA: $20 \mu \mathrm{l}$ of amplicons were taken and $2.5 \mu \mathrm{l}$ of 10X buffer with ATP was added to it. $1 \mu \mathrm{l}$ of pGEM-T Easy vector was added to the mixture followed by $1.5 \mu 1$ of T4 DNA ligase. The mixture was kept overnight at $6{ }^{\circ} \mathrm{C}$ [9]. An aliquot was tested on $1 \%$ agarose gel electrophoresis. 


\subsection{Transformation of $E$. coli}

XLI Blue (Tet') strain was taken and inoculated in Luria broth and shaken overnight. $1 \mathrm{ml}$ of the culture was inoculated in $50 \mathrm{ml}$ Luria broth and was kept in shaker incubator at $37^{\circ} \mathrm{C}$ till the mid log phase $\left(\mathrm{A}_{600} \approx 0.5\right)$. The culture was aseptically centrifuged at $8000 \mathrm{rpm}$ for 10 minutes. Cell pellets so obtained was suspended in $10 \mathrm{ml}$ of $0.1 \mathrm{M} \mathrm{CaCl}_{2}$ followed by centrifugation at $8000 \mathrm{rpm}$ for 10 minutes. The cell pellet was resuspended in $1 \mathrm{ml}$ of $0.1 \mathrm{M} \mathrm{CaCl}_{2} .0 .1 \mathrm{ml}$ aliquot was taken in sterile Eppendorf tube, $5 \mu \mathrm{l}$ of PCR product ligated to pGEM-T Easy vector (Promega) was added for transformation.

The above mixture was kept at $4^{\circ} \mathrm{C}$ for 30 minutes. Heat shock at $42^{\circ} \mathrm{C}$ was given for 45 seconds. $0.5 \mathrm{ml}$ of Luria broth was added to the tube and was incubated at $37^{\circ} \mathrm{C}$ for 45 minutes in an incubator shaker. $0.1 \mathrm{ml}$ aliquot was placed on LB-Ampicilin plates and was incubated overnight at $37^{\circ} \mathrm{C}$. Blue and White colonies were observed. Plasmid preparations from individual white colonies were done using the alkaline lysis method [9] [11] followed by phenol extraction and alcohol precipitation [10].

\subsection{Sequencing}

The insert sequences of $16 \mathrm{~S}$ rDNA in different cloned plasmids were sequenced. The sequencing was outsourced from the companies, Biobharti at Salt Lake, Kolkata and Xcelris at Ahmedabad, India. The primers used for the sequencing reactions were either SP6 promoter or T7 promoter sequences, which flank the inserts in opposite orientation.

\subsection{Methodology for Bioinformatic Analysis}

Nineteen different sequences of $16 \mathrm{~S}$ rDNA were deposited at NCBI. The sequences were published with accession number KF711832-KF711850. To determine the closest resembling species of the new isolates, n-BLAST was performed with the NCBI database and the sequences with maximum e-value with $100 \%$ query coverage were used for outgrouping [12] [13]. The sequences were analyzed by MEGA 5 software, where the sequences in Fasta format were aligned by ClustalW and the alignments were refined manually using the TrimaAl tool. Gaps and ambiguously aligned positions were excluded. Phylogenetic tree was constructed using the MEGA 5 software by the statistical maximum-likelihood method. The bootstrap analysis was carried out on 1000 replicates. Phylogenetic tree was constructed using the Tamura Nei substitution model with gamma distributed (G) using eight rate categories. The detailed phylogenetic tree is appended in the supplement.

\section{Results \& Discussion}

\subsection{Amplification of $16 \mathrm{~S}$ rRNA Genes from the Arctic Consortium}

Using the universal forward and reverse primers for bacterial 16S rDNA sequence, the amplification product with the genomic DNA of the consortium as template was observed in $1.5 \%$ agarose gel electrophoresis. As expected this showed a single DNA band of $1.4 \mathrm{~kb}$ size (Figure 1).

\subsection{Cloning of the Mixed 16S rDNA Sequences}

The different sequences present in the amplified 16S rDNA product were separated by cloning in A:T vector in E. coli XL1-Blue doing the blue-white selection on Ampicillin-X-gal-IPTG plates. The blue colonies arise from cells carrying just the vector and white colonies contain vector with inserts. Randomly picked white colonies were processed for plasmid isolation and sequencing in automated sequencer.

\subsection{Submission of 16S rDNA Sequences and Phylogenetic Analysis}

All the DNA sequences generated from the inserts of the recombinant pGEM-T vector were submitted to the NCBI database and the accession numbers were given to 19 such independent sequences (Table 1). A phylogenetic analysis was conducted using maximum likelihood for the 19 dataset of $16 \mathrm{~S}$ rDNA sequences belong to uncultured and mixed bacterial consortium. A general substitution model (GTR) was applied for analyses. The analyzed 19 dataset of metogenomics dataset of mixed bacterial consortium revealed the occurrence of the major genus belong to the order Bacillales and least number of genus belong to order Hemisptera. The dominant group 


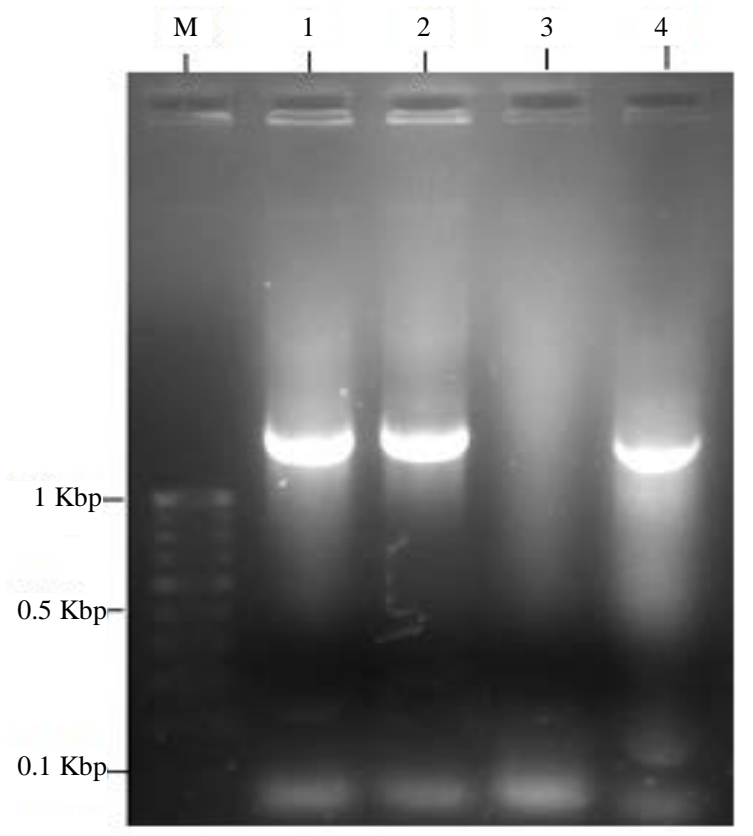

Figure 1. PCR amplified 16S rDNA products from three random mixed genomic DNA samples from Arctic region (Lanes 1, 2, 4). The lane marked M is $100 \mathrm{bp}$ ladder and lane 3 is controlled without any template DNA.

Table 1. Accession numbers provided by NCBI for the isolates from Arctic sample.

\begin{tabular}{|c|c|}
\hline Accession number & Specie identified \\
\hline \multicolumn{2}{|l|}{ Clade 1} \\
\hline KF711834.1 & Uncultured Bacillus sp \\
\hline KF711835.1 & do \\
\hline KF711841.1 & do \\
\hline KF711833.1 & do \\
\hline KF711837.1 & do \\
\hline KF711838.1 & do \\
\hline KF711844.1 & do \\
\hline KF711836.1 & do \\
\hline \multicolumn{2}{|l|}{ Clade 2} \\
\hline KF711832.1 & Uncultured Lysinibacillus sp \\
\hline \multicolumn{2}{|l|}{ Clade 3} \\
\hline KF711840.1 & Uncultured Planomicrobium sp \\
\hline KF711846.1 & Uncultured Bacterium clone \\
\hline KF711839.1 & do \\
\hline \multicolumn{2}{|l|}{ Clade 4} \\
\hline KF711848.1 & do \\
\hline KF711842.1 & Uncultured Bacillus sp \\
\hline KF711845.1 & Uncultured Bacterium clone \\
\hline KF711847.1 & Uncultured Bacillus sp \\
\hline KF711849.1 & Uncultured Bacterium clone \\
\hline \multicolumn{2}{|l|}{ Clade 5} \\
\hline KF711843.1 & Uncultured Bacterium clone \\
\hline KF711850.1 & Uncultured Paenibacilus sp \\
\hline
\end{tabular}




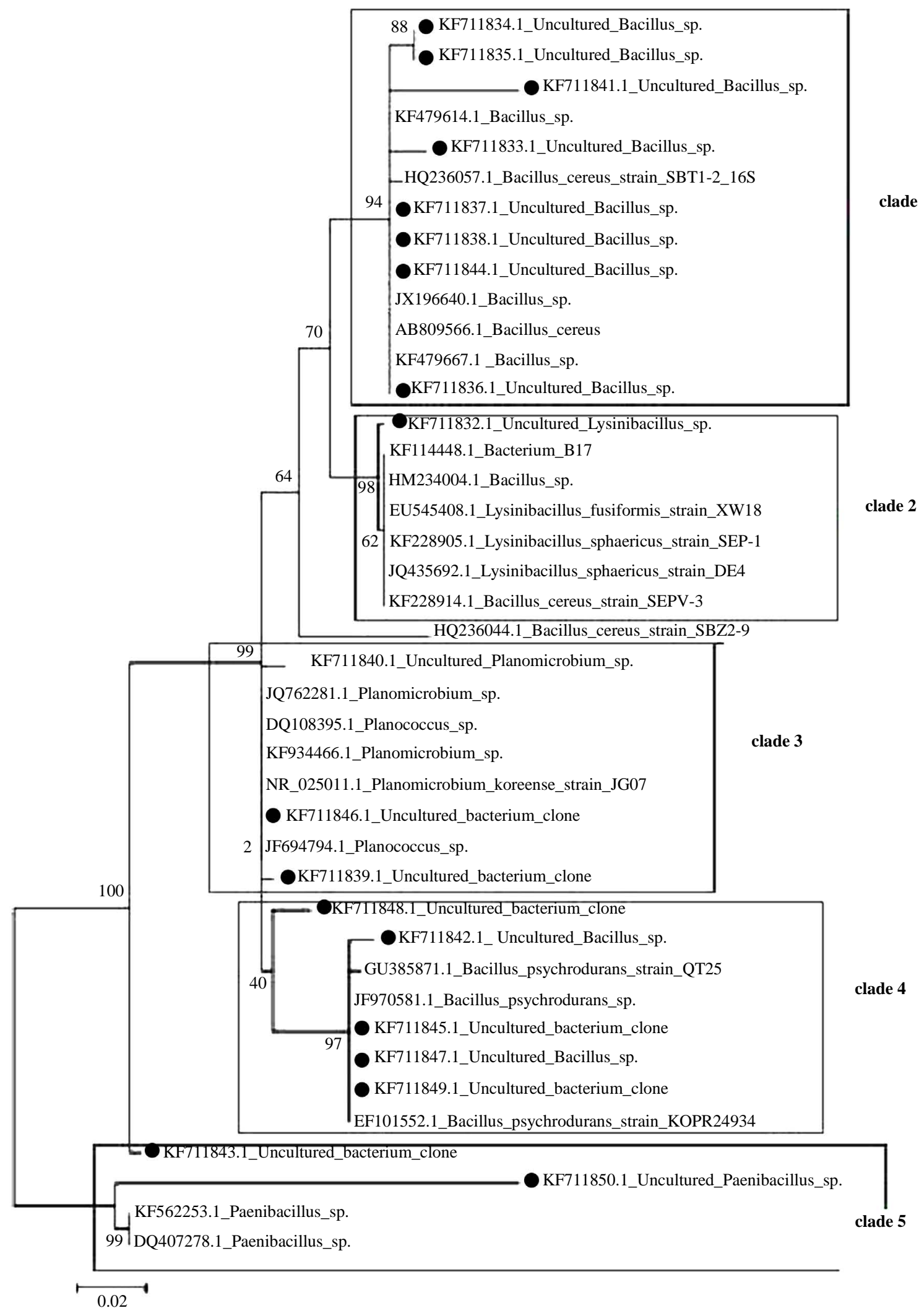

Figure 2. Phylogenetic tree of the arctic microbes. 
in clone library is belonging to order Bacillales which was profound revealed the supremacy of the genus Bacillales phylotypes in soil samples from Ny Alesund (collected location). The 16S rDNA analyses revealed the 99\% affiliation of the gram positive bacteria of order Bacillales to Pseudococcidae. The genera represented in the study are the members of Bacillales i.e., Bacillus, Lysinibacillus, Placomicrobium, Paenibacillus were found to cluster significantly with the possibly similar outgroups (Figure 2).

All these genera belonging to the gram positive bacteria, namely KF711833, 34, 35, 36, 37, 38, 41, 44 were clustered in clade 1 which showed $88 \%$ and $94 \%$ similarity. Clade 4 showed the clustering of the sequences KF711842, 45, 47, 48, 49 which share the phenotype similar to the Bacillus with 97\% similarity. These organisms are aerobic or facultative anaerobic and thrive well in the adverse environmental conditions, as in lack of elements such as phosphorus, nitrogen, or oxygen combined with an excessive supply of carbon sources which substantiates its dominant existence in the regions around Ny Alesund.

KF711832 branched deeply in the clade 2 along with the Genus Lysinibacillus and Bacillus, however, it shares 98\% similarity with Lysinibacillus when compared to Bacillus genus. Lysinibacillus is a common environmental organism which is typically a facultative anaerobe that is resistant to heat, chemical and ultraviolet lights. The members of Planomicrobium, apparently omnipresent, grouped in clade 3, its presence is seemingly second to Bacillus. This organism currently accommodates the aerobic, gram-positive bacteria. In calde 5 the sequences KF711843 and KF711850 were clustered with Genus Paenibacillus with 99\% similarity. Paenibacillus is a genus of facultative anaerobic which is capable of fixing nitrogen, pattern formation and self-organization. It reflects social behaviors of bacteria act as a scratch for the evolutionary development of the collective action of cells in higher organisms. Possibly all isolates identified are facultative anaerobic bacteria which reflects the characteristic of sampling site. The anaerobic conditions developed temporarily may due to the presence of melting ice.

The present study provides the valuable baseline data on the microbial communities in the arctic region around $\mathrm{Ny}$ Alesund $\left(79^{\circ} \mathrm{N}, 11.8^{\circ} \mathrm{E}\right)$, Svalbard, Norway. The phylogenetic analyses would enable us to understand the bacterial diversity in the selected area. The organisms identified in the area are non-affiliated genera, which substantiates that the microenvironment can be a "hot-spot". Analyzing the bacterial communities through phylogenetic analyses may lead to the identification of new organisms with cold adaptation mechanism, which may act as a source for the novel genes and products.

\section{Conclusion}

The present study is aimed at identifying uncultured bacteria from a virgin region of the earth, i.e. North polar soil collected from the northernmost habitable place on earth at $79^{\circ} \mathrm{N}$ and $11.8^{\circ} \mathrm{E}$. Peculiarly, most of the isolates turned out to be Bacillus or Lysinibacillus species. Metagenomic approach provides a powerful tool to isolate and characterize such unculturable species from environmental samples.

\section{Acknowledgements}

The authors acknowledge the support of National Centre for Antarctic \& Ocean Research, Goa under the Ministry of Earth Science, Government of India for the expedition to Ny Alesund in 2009. Prof. P. Roy also thanks Sri M. N. Mandal Endowment funds to Burdwan University for financial support. The help rendered by Prof. D. Prabaharan of Bharathidasan University for bioinformatics and Ankur Neog in preparing the manuscript are gratefully acknowledged.

\section{Declaration}

There is no conflict of interest among the authors regarding the contents of this paper.

\section{References}

[1] Whitman, W.B., Coleman, D.C. and Wiebe, W.J. (1998) Prokaryotes: The Unseen Majority. Proceedings of the National Academy of Sciences of the United States of America, 95, 6578-6583. http://dx.doi.org/10.1073/pnas.95.12.6578

[2] Turnbaugh, P.J. and Gordon, J.I. (2008) An Invitation to the Marriage of Metagenomics and Metabolomics. Cell, 134, 708-713.

[3] Sleator, R.D., Shortall, C. and Hill, C. (2008) Metagenomics. Letters in Applied Microbiology, 47, 361-366. http://dx.doi.org/10.1111/j.1472-765X.2008.02444.x 
[4] Venter, J.C., et al. (2004) Environmental Genome Shotgun Sequencing of the Sargasso Sea. Science, 304, 66-74. http://dx.doi.org/10.1126/science.1093857

[5] Daniel, R. (2005) The Metagenomics of Soil. Nature Reviews Microbiology, 3, 470-478. http://dx.doi.org/10.1038/nrmicro1160

[6] Ferrer, M., Beloqui, A., Timmis, K.N. and Golyshin, P.N. (2009) Metagenomics for Mining New Genetic Resources of Microbial Communities. Journal of Molecular Microbiology and Biotechnology, 16, 109-123. http://dx.doi.org/10.1159/000142898

[7] Handelsman, J. (2004) Metagenomics: Application of Genomics to Uncultured Microorganisms. Microbiology and Molecular Biology Reviews, 68, 669-685. http://dx.doi.org/10.1128/MMBR.68.4.669-685.2004

[8] Pace, N.R., Stahl, D.A., Lane, D.J. and Olsen, G.J. (1985) Analyzing Natural Microbial Populations by rRNA Sequences. ASM News, 51, 4-12.

[9] Maniatis, T., Fritsch, E.F. and Sambrook, J. (1982) Molecular Cloning: A Laboratory Manual. Cold Spring Harbor Laboratory, Cold Spring Harbor, New York.

[10] Mezei, L.M. and Storts, D.R. (1994) Purification of PCR Products. In: Griffin, H.G. and Griffin, A.M., Eds., PCR Technology: Current Innovations, CRC Press, Boca Raton, 21-27.

[11] Birnboim, H.C. and Doly, J. (1979) A Rapid Alkaline Extraction Procedure for Screening Recombinant Plasmid DNA. Nucleic Acids Research, 7, 1513-1523. http://dx.doi.org/10.1093/nar/7.6.1513

[12] Lane, D.J., Pace, B., Olsen, G.J., Stahl, D.A., Sogin, M.L. and Pace, N.R. (1985) Rapid Determination of 16S Ribosomal RNA Sequences for Phylogenetic Analysis. Proceedings of the National Academy of Sciences of the United States of America, 82, 6955-6959. http://dx.doi.org/10.1073/pnas.82.20.6955

[13] Weisburg, W.G., Oyaizu, Y., Oyaizu, H. and Woese, C.R. (1985) Natural Relationship between Bacteroides and Flavobacteria. Journal of Bacteriology, 164, 230-236. 
Scientific Research Publishing (SCIRP) is one of the largest Open Access journal publishers. It is currently publishing more than 200 open access, online, peer-reviewed journals covering a wide range of academic disciplines. SCIRP serves the worldwide academic communities and contributes to the progress and application of science with its publication.

Other selected journals from SCIRP are listed as below. Submit your manuscript to us via either submit@scirp.org or Online Submission Portal.
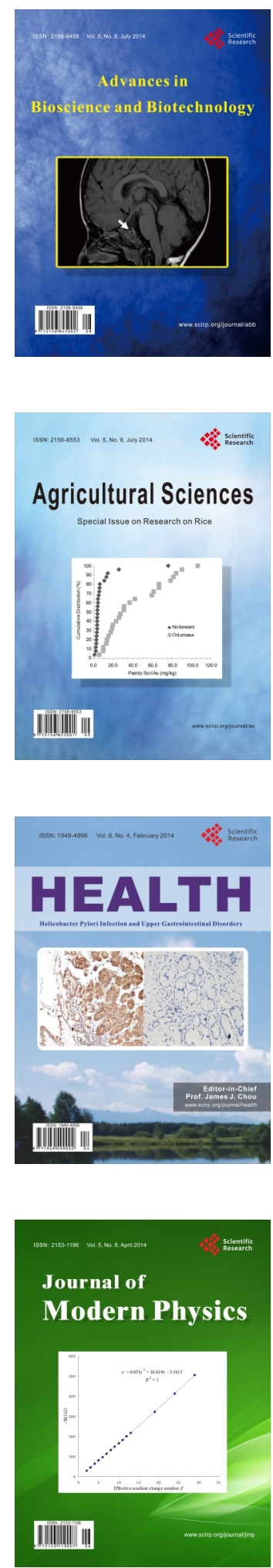
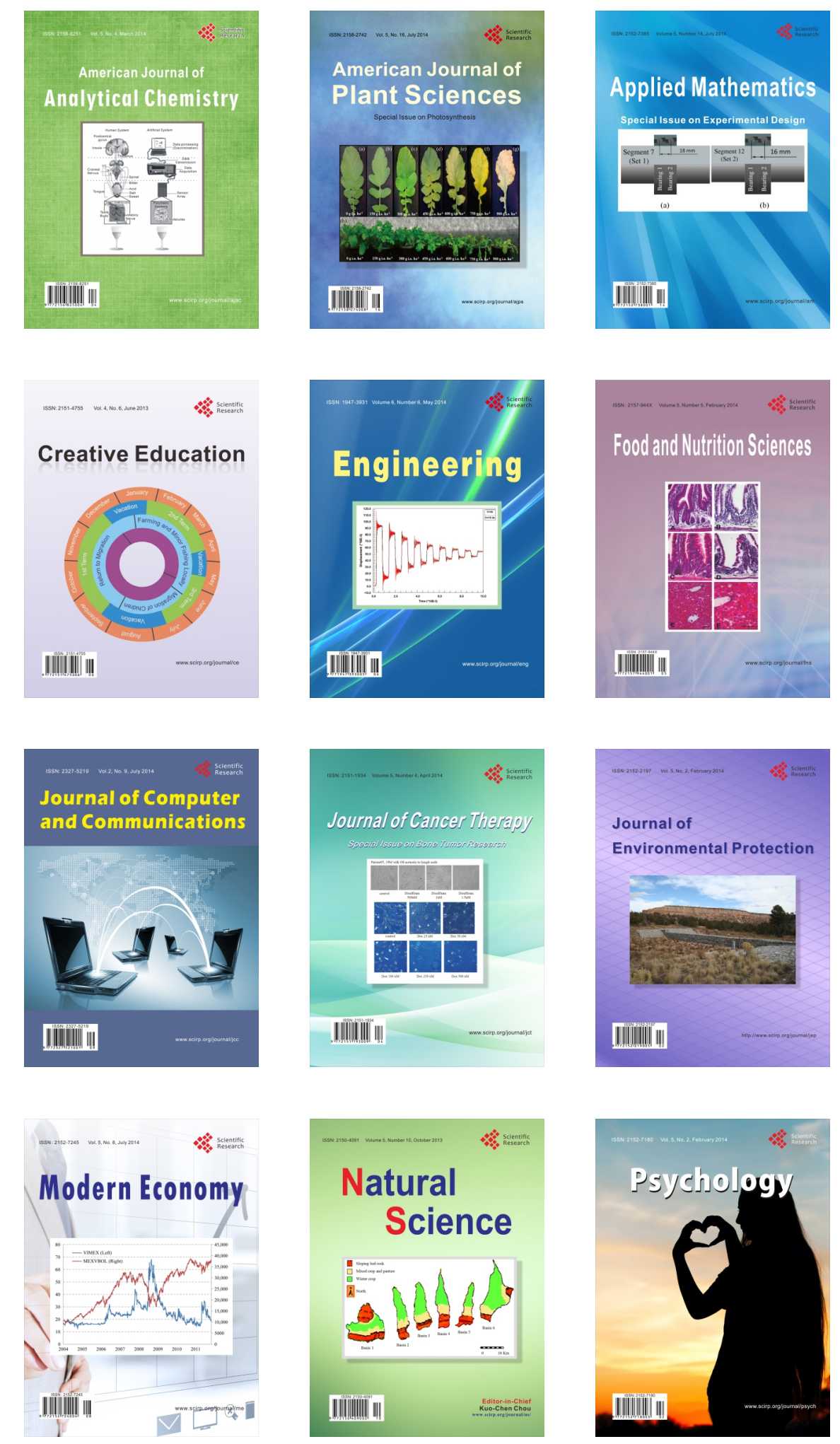